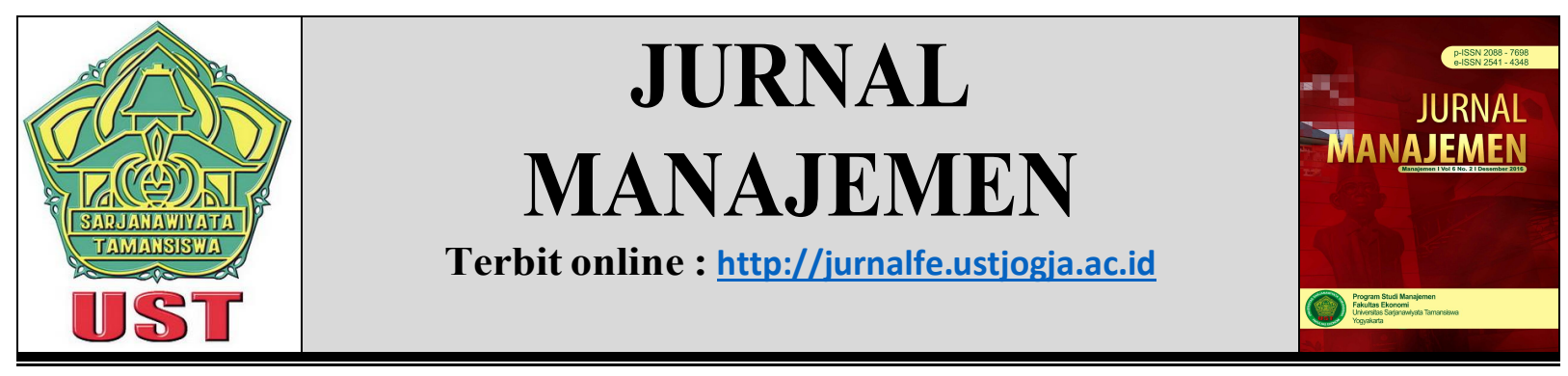

\title{
PENGARUH RAMADHAN TERHADAP RETURN DAN VOLUME PERDAGANGAN SAHAM PADA JAKARTA ISLAMIC INDEX (JII)
}

\author{
Rahayu Setiasri ${ }^{1}$ \\ Risal Rinofah ${ }^{2}$ \\ 1)Alumni Jurusan Manajemen Fakultas Ekonomi Universitas Sarjanawiyata \\ Tamansiswa Yogyakarta \\ 2)Dosen Jurusan Manajemen Fakultas Ekonomi Universitas Universitas \\ Sarjanawiyata Tamansiswa Yogyakarta
}

Korespondensi: izal_7@yahoo.com

\begin{tabular}{ll}
\hline INFORMASI NASKAH & ABSTRAK \\
\hline Alur Naskah: & Tujuan penelitian ini adalah untuk mengetahui apakah \\
Diterima: & terdapat (1) pengaruh Ramadhan terhadap return saham \\
22 Mei 2017 & dan (2) volume perdagangan saham pada Jakarta Islamic \\
Revisi: & Index. \\
28 Mei 2017 & Penelitian ini tergolong dalam jenis penelitian kuantitatif. \\
Diterima untuk terbit: & Populasinya adalah seluruh perusahaan yang terdaftar \\
6 Juni 2017 & dalam Jakarta Islamic Index yang berjumlah 30 perusahaan. \\
Tersedia online: & Teknik analisis data menggunakan uji beda yaitu uji T ( $T$ - \\
30 Juni 2017 & test). \\
\hline Kata Kunci: & Hasil penelitian menunjukkan bahwa pengujian terhadap \\
Ramadhan, Return Saham, & return saham sebelum dan selama Ramadhan, selama dan \\
Volume Perdagangan & sesudah Ramadhan, serta volume perdagangan saham \\
& sebelum dan sesudah Ramadhan tidak berpengaruh secara \\
& signifikan. Hasil yang berbeda didapatkan pada pengujian \\
& volume perdagangan saham selama dan sesudah \\
& Ramadhan, dimana memperoleh hasil yang signifikan
\end{tabular}

\section{PENDAHULUAN}

Pasar modal syariah menjadi alternatif investasi bagi pelaku pasar yang bukan sekedar ingin mendapatkan return terbaik, namun juga dapat memberikan ketenangan dari aktivitas investasinya atau bisa disebut harta atau return yang diperoleh berbentuk halal karena dioperasikan oleh perusahaan yang berlandaskan konsep-konsep Islami. Dalam 
perkembangannya sendiri, pasar modal syariah di Indonesia belum terlalu dikenal dan diminati oleh masyarakat. Hal ini terbukti dengan modal yang masuk dalam JII masih sangat kecil dibandingkan dengan modal yang masuk dalam pasar modal konvensional.

Ramadhan Effect adalah salah satu jenis anomali pasar yaitu anomali musiman yang menunjukkan adanya perbedaan rata-rata return di bulan Ramadhan dibanding dengan bulan lain dalam satu tahun. Fenomena meningkatnya konsumsi masyarakat di bulan Ramadhan ditengarai menjadi suatu fenomena yang menyebabkan return di bulan Ramadhan yang berbeda dengan bulan di luar Ramadhan.

Mustafa (2008) meneliti efek Ramadhan yang diambil dari Daily Business Recorder pada Karachi Stock Exchange - 100 index di Pakistan Periode Maret 1998 - September 2004. Dalam penelitiannya ditemukan bahwa rata-rata return pada bulan Ramadhan lebih rendah dan tidak signifikan namun terdapat rata-rata return yang positif dan signifikan ditemukan pada bulan Syawal dan Ziqad (setelah bulan Ramadhan).

Bialkowski, Etebari, dan Wisniewski dalam Ziemba (2011) meneliti return saham studi selama bulan Ramadhan di 14 negara Muslim selama periode 1989-2007. Mereka menemukan bahwa return saham selama bulan Ramadhan hampir sembilan kali lebih tinggi daripada selama sisa tahun.

Penelitian selanjutnya mengenai anomali Ramadhan effect dilakukan oleh Girard dan Omran (2009) menyimpulkan bahwa return saham syariah pada bulan Ramadhan mengalami kenaikan return saham sehari sebelum hari raya Idul Fitri. Kesimpulannya bahwa bulan Ramadhan berpengaruh positif terhadap return perdagangan saham sayariah di Bursa.

Berdasarkan latar belakang diatas, timbul pertanyaan apakah terdapat perbedaan return saham dan volume perdagangan saham sebelum bulan Ramadhan, selama bulan Ramadhan, dan sesudah bulan Ramadhan, khususnya pada perusahaan yang bergabung dalam Jakarta Islamic Index. Oleh karena itu penulis tertarik untuk melakukan penelitian yang berjudul: "Pengaruh Ramadhan terhadap Return Saham dan Volume Perdagangan Saham pada Jakarta Islamic Index (JII)"

\section{KAJIAN PUSTAKA DAN HIPOTESIS}

\section{a. Return Saham}

Return saham adalah tingkat keuntungan yang dinikmati oleh pemodal atas suatu investasi yang dilakukannya (Robert Ang, 2001).

\section{b. Abnormal Return}

Abnormal return adalah return yang didapat investor yang tidak sesuai dengan pengharapan. Abnormal return adalah selisih antara return yang diharapkan dengan return yang didapatkan. Selisih return akan positif jika return yang didapatkan lebih besar dari return yang diharapkan atau return yang dihitung. Sedangkan return akan negatif jika return yang didapat lebih kecil dari return yang diharapkan atau return yang dihitung.

\section{c. Volume perdagangan saham}

Volume perdagangan saham merupakan jumlah lembar saham yang diperdagangkan secara harian. Adapun volume perdagangan adalah jumlah lembar saham suatu perusahaan yang diperdagangkan dalam waktu tertentu.

\section{d. Pasar Efsien}


Pasar efisien adalah pasar sekuritas yang harga sekuritasnya benar-benar mencerminkan informasi yang ada (stock prices reflect all available information) (1970, dalam Jogiyanto, 2013).

\section{e. Anomali Pasar}

Anomali pasar merupakan penyimpangan terhadap konsep pasar efisien yang penyebabnya sulit dijelaskan dengan cepat (Alteza, 2006)

\section{f. Ramadhan Effect}

Ramadhan Effect adalah salah satu jenis anomali pasar yaitu anomaly musiman yang menunjukkan adanya perbedaan rata-rata return yang lebih tinggi di Bulan Ramadhan dibandingkan dengan bulan lain dalam satu tahun (Akrami et al, 2012).

\section{METODE PENELITIAN}

Penelitian ini menggunakan pendekatan kuantitatif, karena menitikberatkan pada pembuktian ada atau tidaknya Ramadhan effect di Indonesia selama bulan Ramadan. Penelitian dilakukan pada Jakarta Islamic Index (JII) selama tanggal 9 Mei sampai dengan 5 Agustus 2016 untuk menganalisa perilaku investor selama hari-hari di bulan Ramadan terkait aktifitas perdagangan sahamnya.

Metode pengumpulan data yang digunakan adalah dokumentasi. Dalam penelitian ini dokumentasinya berupa laporan historis pergerakan harga saham dan volume perdagangan saham harian yang diperoleh dari direktoril finansial situs Yahoo!.

Untuk menguji dampak Ramadhan terhadap return maupun volume perdagangan dilakukan melalui uji beda

\section{HASIL DAN PEMBAHASAN}

Tabel 1.

Deskripsi Statistik

\begin{tabular}{|l|l|r|r|}
\hline & $\mathrm{N}$ & \multicolumn{1}{|c|}{ Mean } & \multicolumn{1}{c|}{ Std. Deviation } \\
\hline Abnormal Sebelum & 27 & 70,33 & 334,914 \\
\hline Abnormal Selama & 27 & 140,04 & 361,135 \\
\hline Abnormal Sesudah & 27 & 49,59 & 591,573 \\
\hline Volume Sebelum & 27 & $25.388 .798,52$ & $25.806 .216,455$ \\
\hline Volume Selama & 27 & $30.054 .723,26$ & $32.309 .139,202$ \\
\hline Volume Sesudah & 27 & $32.830 .738,78$ & $32.076 .476,788$ \\
\hline
\end{tabular}

Sumber : Hasil Pengujian Penelit, 2016

Dari tabel 1 diketahui bahwa :

1. Rata-rata return saham baik sebelum, selama, dan sesudah Ramadhan lebih kecil dari pada standar deviasinya menunjukkan semakin besar penyimpangan nilai terhadap rataratanya, atau dapat dikatakan tidak terdistribusi dengan baik.

2. Rata-rata volume perdagangan saham sebelum dan selama bulan Ramadhan lebih kecil dari standar deviasinya menunjukkan bahwa terjadi penyimpangan dari nilai rata-ratanya, sedangkan pada rata-rata volume perdagangan saham sesudah bulan Ramadhan lebih besar dari standar deviasinya menunjukkan bahwa semakin kecil penyimpangan terhadap rata-ratanya. 


\section{Analisis Data}

\section{a) Pengujian Normalitas Data Variabel Return Saham}

Tabel 2.

Hasil Uji Normalitas Data Variabel Return Saham Sebelum, Selama, dan Sesudah Bulan Ramadhan

\begin{tabular}{|l|c|c|}
\hline & Sig. & Ket. \\
\hline Return saham sebelum Ramadhan & 0,200 & Normal \\
\hline Return saham selama Ramadhan & 0,200 & Normal \\
\hline Return saham sesudah Ramadhan & 0,093 & Normal \\
\hline
\end{tabular}

Sumber : Hasil Pengujian Penelit, 2016

Tabel 2. menunjukkan bahwa tingkat signifikan dari data variabel return saham sebelum, selama dan sesudah Ramadhan lebih dari 0,05. Hasil ini berarti bahwa data sudah terdistribusi dengan normal.

\section{b) Pengujian Normalitas Data Variabel Volume Perdagangan Saham}

Tabel 3.

Hasil Uji Normalitas Data Variabel Volume Perdagangan Saham Sebelum, Selama, dan Sesudah Bulan Ramadhan

\begin{tabular}{|l|c|c|}
\hline & Sig. & Ket. \\
\hline $\begin{array}{l}\text { Volume perdagangan saham sebelum } \\
\text { Ramadhan }\end{array}$ & 0,000 & Tidak normal \\
\hline $\begin{array}{l}\text { Volume perdagangan saham selama } \\
\text { Ramadhan }\end{array}$ & 0,006 & Tidak normal \\
\hline $\begin{array}{l}\text { Volume perdagangan saham sesudah } \\
\text { Ramadhan }\end{array}$ & 0,044 & Tidak normal \\
\hline
\end{tabular}

Sumber : Hasil Pengujian Penelit, 2016

Tabel 3. menunjukkan bahwa tingkat signifikan dari data variabel volume perdagangan saham sebelum, selama dan sesudah Ramadhan kurang dari 0,05. Hasil ini berarti bahwa data tidak terdistribusi dengan normal, oleh karena itu penulis merubah data dengan fungsi LN (Logaritma Natural) agar data volume perdagangan saham sebeulum, selama dan sesudah bulan Ramadhan dapat terdistribusi dengan normal.

\section{Tabel 4.}

Hasil Uji Normalitas Data Variabel Volume Perdagangan Saham Sebelum, Selama, dan Sesudah Bulan Ramadhan setelah di rubah dengan fungsi LN

\begin{tabular}{|l|r|r|}
\hline & Sig. & Ket. \\
\hline $\begin{array}{l}\text { Volume perdagangan saham } \\
\text { sebelum Ramadhan }\end{array}$ & 0,102 & Normal \\
\hline $\begin{array}{l}\text { Volume perdagangan saham selama } \\
\text { Ramadhan }\end{array}$ & 0,200 & Normal \\
\hline $\begin{array}{l}\text { Volume perdagangan saham sesudah } \\
\text { Ramadhan }\end{array}$ & 0,169 & Normal \\
\hline
\end{tabular}

Sumber : Hasil Pengujian Penelit, 2016 
Tabel 4. menunjukkan bahwa tingkat signifikan dari data variabel volume perdagangan saham sebelum, selama dan sesudah Ramadhan seteah dirubah dengan fungsi LN lebih dari 0,05. Hasil ini berarti bahwa data sudah terdistribusi dengan normal.

\section{Pengujian Hipotesis Hipotesis Pertama}

Tabel 5.

Hasil Uji Beda Rata-rata Return Saham Sebelum dan Selama bulan Ramadhan Paired Sampel Test

\begin{tabular}{|l|c|r|}
\hline & $\mathrm{t}$ & Sig. (2-tailed) \\
\hline $\begin{array}{l}\text { Return saham Sebelum Ramadhan - Return } \\
\text { saham Selama Ramadhan }\end{array}$ & $-0,885$ & 0,384 \\
\hline
\end{tabular}

Sumber : Hasil Pengujian Penelit, 2016

Pada tabel 5 dapat dilihat bahwa sig. 0,384 > dari tingkat signifikansi 0,05. Hal ini dapat disimpulkan bahwa tidak terdapat perbedaan return saham yang signifikan pada periode sebelum dan selama Ramadhan, artinya hipotesis pertama tidak terbukti.

\section{Hipotesis Kedua}

Tabel 6.

Hasil Uji Beda Rata-rata Return Saham Selama dan Sesudah bulan Ramadhan Paired Sampel Test

\begin{tabular}{|c|c|c|}
\hline & $\mathrm{t}$ & $\begin{array}{c}\text { Sig. (2- } \\
\text { tailed) }\end{array}$ \\
\hline $\begin{array}{l}\text { Return saham Selama Ramadhan - } \\
\text { Return saham Sesudah Ramadhan }\end{array}$ & 0,624 & 0,538 \\
\hline
\end{tabular}

Sumber : Hasil Pengujian Penelit, 2016

Pada tabel 6. dapat dilihat bahwa sig. 0,538 > dari tingkat signifikansi 0,05. Hal ini dapat disimpulkan bahwa tidak terdapat perbedaan return saham yang signifikan pada periode selama dan sesudah Ramadhan, artinya hipotesis kedua tidak terbukti.

\section{Hipotesis Ketiga}

Tabel 7.

Hasil Uji Beda Rata-rata Volume Perdagangan Saham Sebelum dan Selama

Ramadhan

Paired Sampel Test

\begin{tabular}{|l|r|r|}
\hline & $\mathrm{t}$ & $\begin{array}{c}\text { Sig. (2- } \\
\text { tailed) }\end{array}$ \\
\hline $\begin{array}{l}\text { Volume perdagangan saham } \\
\text { Selama Ramadhan - Volume } \\
\text { perdagangan saham Sesudah } \\
\text { Ramadhan }\end{array}$ & 1,416 & 0,169 \\
\hline
\end{tabular}

Sumber : Hasil Pengujian Penelit, 2016

Pada tabel 7. dapat dilihat bahwa sig. 0,169> dari tingkat signifikansi 0,05. Hal ini dapat disimpulkan bahwa tidak terdapat perbedaan volume perdagangan saham yang signifikan pada periode sebelum dan selama Ramadhan, artinya hipotesis ketiga tidak terbukti. 


\section{Hipotesis Keempat}

Tabel 8.

Hasil Uji Beda Rata-rata Volume Perdagangan Saham Selama dan Sesudah bulan Ramadhan

Paired Sampel Test

\begin{tabular}{|l|r|r|}
\hline & $\mathrm{t}$ & $\begin{array}{c}\text { Sig. (2- } \\
\text { tailed) }\end{array}$ \\
\hline $\begin{array}{l}\text { Volume perdagangan saham } \\
\begin{array}{l}\text { Selama Ramadhan - Volume } \\
\text { perdagangan saham Sesudah } \\
\text { Ramadhan }\end{array}\end{array}$ & 2,207 & 0,036 \\
\hline
\end{tabular}

Sumber : Hasil Pengujian Penelit, 2016

Pada tabel .8 dapat dilihat bahwa sig. $0,036<$ dari tingkat signifikansi 0,05 . Hal ini dapat disimpulkan bahwa terdapat perbedaan volume perdagangan saham yang signifikan pada periode selama dan sesudah Ramadhan, artinya hipotesis keempat terbukti.

\section{Pembahasan}

\section{Hipotesis 1}

Hipotesis pertama dalam penelitian ini menyatakan bahwa terdapat perbedaan return saham yang signifikan pada periode sebelum dan selama Ramadhan, tetapi dari hasil pengujian menujukkan bahwa tidak terdapat perbedaan return saham yang signifikan pada periode sebelum dan selama Ramadhan, sehingga hipotesis yang yang menyatakan bahwa terdapat perbedaan return saham yang signifikan pada periode sebelum dan selama Ramadhan tidak terbukti.

Return saham pada periode sebelum Ramadhan dengan selama Ramadhan ini sebenarnya mengalami kenaikan yang tinggi yaitu $99,12 \%$ yang dapat dilihat dari rata-rata return periode sebelum Ramadhan sebesar 70,33 menjadi 140,04 pada periode selama Ramadhan. Akan tetapi dari hasil pengujian dikatakan tidak signifikan karena kenaikan yang terjadi tidak melebihi standard deviation. Penyebab utama tidak signifikannya return periode sebelum Ramadhan dengan periode selama Ramadhan adalah komposisi investor di Indonesia yang masih didominasi oleh investor asing yaitu sebesar 64\%, adapun investor lokal hanya sebesar 36\% (tempo.co, per 29 juni 2016).

\section{Hipotesis 2}

Hipotesis kedua dalam penelitian ini menyatakan bahwa terdapat perbedaan return saham yang signifikan pada periode selama dan sesudah Ramadhan tetapi dari hasil pengujian menujukkan bahwa tidak terdapat perbedaan return saham yang signifikan pada periode selama dan sesudah Ramadhan, sehingga hipotesis yang yang menyatakan bahwa terdapat perbedaan return saham yang signifikan pada periode selama dan sesudah Ramadhan tidak terbukti.

Return saham pada periode selama Ramadhan dengan sesudah Ramadhan ini sebenarnya mengalami penurunan tinggi yaitu $182,40 \%$ yang dapat dilihat dari rata-rata return periode selama Ramadhan sebesar 140.04 menjadi 49,59 pada periode sesudah Ramadhan. Akan tetapi dari hasil pengujian dikatakan tidak signifikan karena kenaikan yang terjadi tidak 
melebihi standard deviation. Penyebab utama tidak signifikannya return periode selama Ramadhan dengan periode sesudah Ramadhan adalah komposisi investor di Indonesia yang masih didominasi oleh investor asing yaitu sebesar 64\%, adapun investor lokal hanya sebesar $36 \%$ (tempo.co, per 29 juni 2016).

\section{Hipotesis 3}

Hipotesis ketiga dalam penelitian ini menyatakan bahwa terdapat perbedaan volume perdagangan saham yang signifikan pada periode sebelum dan selama Ramadhan tetapi dari hasil pengujian menujukkan bahwa tidak terdapat perbedaan volume perdagangan saham yang signifikan pada periode sebelum dan selama Ramadhan, sehingga hipotesis yang yang menyatakan bahwa terdapat perbedaan volume perdagangan saham yang signifikan pada periode sebelum dan sesudah Ramadhan tidak terbukti.

Volume perdagangan saham pada periode sebelum Ramadhan dengan selama Ramadhan ini sebenarnya mengalami peningkatan cukup tinggi yaitu 18,38\% yang dapat dilihat dari rata-rata volume perdagangan saham periode sebelum Ramadhan sebesar 25.388.798,52 menjadi 30.054.723,26 pada periode selama Ramadhan. Akan tetapi dari hasil pengujian dikatakan tidak signifikan karena kenaikan yang terjadi tidak melebihi standard deviation. Penyebab utama tidak signifikannya volume perdagangan saham periode sebelum Ramadhan dengan periode selama Ramadhan adalah komposisi investor di Indonesia yang masih didominasi oleh investor asing yaitu sebesar 64\%, adapun investor lokal hanya sebesar $36 \%$ (tempo.co, per 29 juni 2016).

\section{Hipotesis 4}

Hipotesis keempat dalam penelitian ini menyatakan bahwa terdapat perbedaan volume perdagangan saham yang signifikan pada periode selama dan sesudah Ramadhan, dan dari hasil pengujian menujukkan bahwa terdapat perbedaan volume perdagangan saham yang signifikan pada periode selama dan sesudah Ramadhan, sehingga hipotesis yang yang menyatakan bahwa terdapat perbedaan volume perdagangan saham yang signifikan pada periode selama dan sesudah Ramadhan terbukti. Akan tetapi teori tentang turunnya volume perdagangan saham selama periode sesudah Ramadhan tidak terbukti. Penyebabnya adalah komposisi investor di Indonesia yang masih didominasi oleh investor asing yaitu sebesar 64\%, adapun investor lokal hanya sebesar 36\% (tempo.co, per 29 juni 2016). Hal tersebut yang mengakibatkan volume perdagangan saham pada periode sesudah Ramadhan meningkat 9,24\% dari 30.054.723,26 pada periode selama Ramadhan menjadi $32.830 .738,78$ pada periode sesudah Ramadhan.

\section{PENUTUP}

Berdasarkan analisis yang dilakukan terhadap hipotesis, maka dapat diambil kesimpulan sebagai berikut :

1. Dari hasil uji beda return saham pada periode sebelum dan selama Ramadhan diketahui bahwa sig. 0,384 lebih besar dari tingkat signifikansi 0,05 artinya hipotesis pertama tidak terbukti.

2. Dari hasil uji beda return saham pada periode selama dan sesudah Ramadhan diketahui bahwa sig. 0,538 lebih besar dari tingkat signifikansi 0,05 artinya hipotesis kedua tidak terbukti.

3. Dari hasil uji beda volume perdagangan saham pada periode sebelum dan selama Ramadhan diketahui bahwa sig. 0,169 lebih besar dari tingkat signifikansi 0,05 artinya hipotesis ketiga tidak terbukti. 
4. Dari hasil uji beda volume perdagangan saham pada periode selama dan sesudah Ramadhan diketahui bahwa sig. 0,036 lebih kecil dari tingkat signifikansi 0,05 artinya hipotesis keempat terbukti.

\section{DAFTAR PUSTAKA}

A'immah, Syarifatul, Suhadak, dan Raden Rustam Hidayat., 2015. "Reaksi Abnormal Return dan Trading Volume Actifity terhadap Ramadhan Effect". Jurnal Administrasi Bisnis (JAB), Vol. 27, No. 1

Ang, Robert., 1997. Buku Pintar Pasar Modal Indonesia Edisi I. Indonesia

Anwar, Syamsul., 2015. "Efek Ramadhan terhadap Abnormal Return dan Volume Perdagangan Saham pada Perusahaan yang masuk dalam Jakarta Islamic Index”. Skripsi

Bialkowski, Ahmad Etebari, and Tomasz Piotr Wisniewski., 2010. "Piety and Profits: Stock Market Anomaly during the Muslim Holy Month". Tesis Rusmayanti, Aprida, Meina Wulansari Yusniar, dan Asrid Juniar., 2016. "Pengaruh Bulan Ramadhan terhadap Return Pasar Saham di Bursa Efek Indonesia (1425H-1434H)”. Jurnal Wawasan Manajemen, Vol. 4, No. 1

Fama, E.F., 1970. "Efficient Capital Market : A riview of theory and empirical work". Journal of Finance, Vol.25 pp, 383-417

Fitriyana., 2014. "Analisis Pengaruh Frekuensi Perdagangan, Volume Perdagangan, Kapitalisasi Pasar, Hari Perdagangan, dan Laba terhadap Return Saham (Studi Empiris pada Perusahaan Manufaktur yang Terdaftar di BEI)". Naskah Publikasi Ilmiah

Gumanti, Tatang A., dan Elok Sri Utami., 2002. "Bentuk Pasar Efisien dan Pengujiannya". Jurnal Akuntansi \& Keuangan, Vol. 4, No. 1

Hendrawijaya, Michael., 2009. "Analisis Perbandingan Harga Saham, Volume Perdagangan Saham, dan Abnormal Return Sebelum dan Sesudah Pemecahan Saham (Studi pada perusahaan go public yang melakukan pemecahan saham antara tahun 2005 - 2008 di BEI)". Tesis

Hinawati, Titik., 2015. "Efek Hari Libur Idul Fitri terhadap Abnormal Return Saham di Bursa Efek Indonesia". Tesis

Malasari, Arnisa J.M., 2014. "Efek Hari Libur Islam terhadap Return, Abnormal Return, dan Volume Perdagangan Saham pada Perusahaan yang masuk dalam Daftar Efek Syariah Periode 2007-2013". Skripsi

Masjid, M. Shabri Abd., dan Cut Windasari., 2015. "Analisis Return dan Kalender Anomali: Studi Komparatif Antara Saham Syariah dan Konvensional Di Indonesia”. Human Falah, Vol. 2, No. 1

Mustafa, Khalid., 2011. "The Islamic Calendar Effect On Karachi Stock Market, Presented at the 8th International Business Research Conference, on March 27-28, 2008 Crowne Plaza Hotel Dubai, UAE" 